\title{
Representative and Commissive Illocutionary Acts in Donald Trump's Inauguration Speech
}

\author{
Putu Diah Sekar Pratiwi Putri \\ English Department - Faculty of Arts - Udayana University \\ [diaah320@gmail.com]
}

\begin{abstract}
This paper is entitled Representative and Commissive Illocutionary Acts in Donald Trump's Inauguration Speech. The aims of this study are to find out the classification and the intended meaning of the representative and commissive illocutionary act found in the speech. The research method used in the study was qualitative analysis method. The data were collected from the Donald Trump's inauguration speech transcript and then identified the function of the illocutionary act and explained the intended meaning. Based on the analysis, the functions of the representative illocutionary act that were found are stating, predicting. affirming, describing and denying. Meanwhile, the function types of commissive illocutionary act are assuring, promising and pledging. The intended meanings that were found in the context of situation analysis are presenting, unifying, revealing, clarifying, convincing and committing.
\end{abstract}

Keywords: representative, commissive, illocutionary act, context of situation

\section{Abstrak}

Makalah ini berjudul Representatif dan Komisif Illocutionary Acts di Pidato Inagurasi Donald Trump. Tujuan dari penelitian ini adalah untuk mengetahui klasifikasi dan arti yang dimaksudkan dari ilokusi representatif dan komisif yang ditemukan dalam pidato. Metode penelitian yang digunakan dalam penelitian ini adalah metode analisis kualitatif. Data dikumpulkan dari transkrip pidato inagurasi Donald Trump dan kemudian mengidentifikasi fungsi dari tindakan ilokusi dan menjelaskan makna yang dimaksudkan. Berdasarkan analisis, fungsi tindakan ilokusi representatif yang ditemukan menyatakan, memprediksi, menegaskan, mendeskripsikan dan menyangkal. Sementara itu, jenis-jenis fungsi tindakan ilokusi yang bersifat komisif adalah meyakinkan, menjanjikan dan mengikrarkan. Makna yang dimaksudkan yang ditemukan dengan konteks analisis situasi adalah penyajian, pemersatu, pengungkapan, klarifikasi, penyakinan dan komitmen.

Kata kunci: tindakan representatif, tindakan komisif, ilokusi, konteks situasi

\section{Background of the Study}

People use words for all of sorts of things such as making a request, statements, promises, giving thanks, orders, asking questions, offering apologies and so on. All of those are represented in their communication of daily life. Besides expressing what the speaker's mind and their want, utterances can also show the relationship between the speaker and the hearer. 
Communication has a major contribution to establishing the social order, it is a representation of how someone acts towards the other and upon the world. In communication, language is used to help people as the performing function as intended by the user.

Speech act is the smallest unit of human communication similar to the word for the smallest form found in language and morpheme as the smallest grammatical unit of a language that can not be further divided.

Practically, political discourse as one of the genre in communication, shows how the speech act, especially illocutionary works. Political discourse usually has a purpose to gather people, get support from a larger population, to influence a larger population then it will affect the process of making the policies or regulation. Political discourse make use of all the illocutionary features in its process, for example, when a politician delivers a speech and describes a temporal situation, delivers his intention from the communication, his ability to change the state of the world and delivers a set of condition of success, a promising and the effect which comes from the utterances. In this study, the analysis was conducted with an inauguration speech from a President as a sample of political discourse as well as its object. Inauguration speech typically embraces broad themes regarding the development, from times to times, either getting better, stuck or coming down, often carrying out strong messages regarding patriotism and promises. Therefore, political discourse was chosen as the object because it uses all the features of speech act.

This study analyzed the illocutionary force of the representative and commissive illocutionary act used in the inaugural speech of Trump with the theory of Taxonomy of Illocutionary by
J.R. Searle (1976) and Performative Verbs by Daniel Vanderveken from his book (1990) as the support theory. Moreover, context of situation theory from Halliday (1985) was used to analyze the explanation of the situation to help determine the function of the illocutionary force.

\section{Problem of the Study}

Based on the above background, the problem was formulated as follows:

a. What kind of the representative and commissive illocutionary act was found in the Donald Trump's inaugural speech?

b. What are the intended meanings of the representative and commissive illocutionary acts found in the Donald Trump's inaugural speech?

\section{Aim of the Study}

The aims of the study are as follows:

a. To identify representative and commissive illocutionary act found in the Donald Trump's inauguration speech.

b. To explain the intended meaning of representative and commisive illocutionary act found in the Donald Trump's inauguration speech.

\section{Research Method}

The data were taken from the Donald Trump's inauguration speech; the format data is the transcript of his speech that downloaded from the White House website (www.whitehouse.gov/inauguraladdress).

The data were collected by watching the video of the inauguration speech and matching it with the transcript that had been downloaded. Then, the data were sorted out based on the theory applied 
This study used the qualitative method to analyze the data. Firstly, reading through the transcript and then selecting the utterance which contains representative and commissive illocutionary act distinction according to Searle (1976) and then noted it down.

At first, the analysis was presented by showing the selected data in the form of a sentence. Then, the utterance that was analyzed was noted in italic so it was helped to explain the part which was being analyzed without getting confused. Afterwards, the results of the analysis were presented descriptively below the utterance.

\section{Findings and Discussion}

\subsection{Representative}

\section{(RIA/46-113)}

And whether a child is born in the urban sprawl of Detroit or the windswept plains of Nebraska, they look up at the same night sky, they fill their heart with the same dreams, and they are infused with the breath of life by the same almighty Creator.

\section{a. Classification of Illocutionary}

The utterance shows a representative illocutionary act in function of describing. According to Searle (1976), the representative illocutionary act has words to world direction fit. Trump's utterance was explaining the situation of the people living in America as its citizens. This statement was delivered to the audiences to explain to them that they share the same dreams and they lived in the country as a union. This statement was delivered to unify them.

Vanderveken (1990) describe it as a series of assertions in general, in the context of a conversation where the subject is in the discussion and more complete information on it considered relevant.

These are four main conditions underlying the utterance:

a. Proposition condition: Trump delivered unifying words such as they share the same dreams and breath of life by the same almighty to get their empathy.

b. Preparatory condition: Trump's presidential period will begin and he needs to make sure that the Americans were on his side to work together to make a better country that they have been dreaming about. Therefore, he delivered those words to get their empathy and then get their support and they can unite to work together.

c. Sincerity condition: Trump believed that all of American citizens have the same dreams of a better future for their country; therefore, he knew that to state this out might get their empathy to support him.

d. Essential condition: It was counted as an attempt of Trump to state the unifying words to get the American empathy and support.

\section{b. Context of Situation}

a. Field

Trump draw a message in the utterance above that every child from all over the places in America no matter how their situation is, they have the same dream and the same right to make it come true. Since it was his inauguration he made sure that people know this and he acknowledges this fact.

b. Tenor

Trump as the new president spoke for his citizens that everyone has the same rights to have the same dream and make it come true. Therefore, the participants in the utterance are Trump as 
the speaker and when this is an inauguration of a great country the hearer is the people around the world either they attend the inauguration place or watching or listening from a media.

\section{c. Mode}

This utterance seemed to be a poetic line of his speech as a unifying rhetorical flourish. He used sprawl and windswept as the metaphor of the poor people from some places in America. He told the audiences that every child in America has the right to have a dream and make it come true.

The utterance above might have different intended meaning if it has a different context of situation from Trump such as when a teacher and a student had a discussion about differences in society then the intended meaning would be educating. Meanwhile, if the intended meaning was analyzed from the context of situation above, the intended meaning from the utterance is unifying American from all over the place in the country that they share the same dream and even though the condition or even their skin color is different but they have a similar identity.

\subsection{Commissive}

\section{(CIA/22-85)}

and unite the civilized world against Radical Islamic Terrorism, which we will eradicate completely from the face of the Earth.

\section{a. Classification of Illocutionary Act}

Trump performed a promising act of commissive in the utterance above. According to Vanderveken (1990) promise act has a preparatory condition which benefits the hearer and this act also involves commitment. The degree of sincerity strength increased due to the explicit undertaking of an obligation.
The four main conditions underlying the utterance are:

a. Proposition condition: The proposition contains in the commissive illocutionary act is $\mathrm{S}$ predicates a future action. Trump predicated to eradicate Radical Islamic Terrorism.

b. Preparatory condition: One of commissive's preparatory condition is $\mathrm{H}$ who wants $\mathrm{S}$ to perform $\mathrm{A}$. The citizens of a country, the people who want to be protected especially with the rise terrorism incidents and as a new president Trump knew that Americans want to be protected from terrorism.

c. Sincerity condition: There are two sincerity conditions in commissive in which $\mathrm{S}$ expresses an intention to do $\mathrm{A}$ and $\mathrm{S}$ intends to do A. From the utterance above, Trump intended to protect America from terrorism.

d. Essential condition: an essential condition in commissive is counted as an undertaking obligation of $\mathrm{S}$ to do A. By uttering the utterance above, Trump as the new president was under the obligation to protect the country from terrorism.

\section{b. Context of Situation}

a. Field

A commissive utterance about develop the relationship of alliances to reinforce the old and make new ones. Terrorism, as well as a group of terrorists such as Al-Qaeda, Taliban, and ISIS which are lately become a concern of the world, might make Trump put this matter into his speech as he also concerns about it. He did make a promise to make some more alliances and reinforces the old one and eradicates the terrorism, however, he did not mention the detail how he would do it. 


\section{b. Tenor}

This utterance is a promise to the citizens of America as well as people in another country. The other countries might already prepare and think how they would alliance with America since Trump mentioned it. Then, this utterances might bring a message towards the terrorist as it becomes an alarm to the terrorist group. Therefore, the participants in the utterance are Trump as the speaker and people who attend the inauguration as well as who were watching or listening to it as the hearer.

c. Mode

In a sentence, Trump managed to deliver an assurance and threaten at the same time. The message in the utterance above might become an alarm to the groups such as Taliban, Al-Qaeda, and ISIS. Furthermore, parts of the sentence "eradicate completely from the face of the Earth" can be classified as hyperbole due to the fact that it is possible to reduce the terrorism, America could eradicate the radical Islamic terrorism from their country or in Europe; however, it is quite hard in the Middle East country where the groups are originated and gain an amount of support.

The utterance above would have different intended meaning if the addressee was direct to the terrorist, the intended meaning would be threatening. According to the analysis above, the intended meaning of the utterance is committing. Trump committed to make new alliances and reinforce the old one and eradicate the radical Islamic terrorism.

\section{Conclusions}

Based on the result of the analysis that had been done in the third chapter, there are two points that can be concluded related to the problems formulated in the first chapter.
All function types of representative illocutionary were found in the Donald Trump's inauguration speech on 20th January 2017, they are: stating, predicting. affirming, describing and denying. Meanwhile, the function types of commissive illocutionary act are assuring, promising and pledging.

The intended meanings found from representative and commissive illocutionary act are presenting, unifying, revealing, clarifying, convincing, committing and threatening. The context of situation elements are field which refers to the on going activity, reflection of the situation in which a text or utterance occured and also the nature of the social action which is taking place; tenor refers to the people who invloves, their status and roles, and their relationship between the participants, it highlights that language is also affected by social relationship between the participants who are involved; mode refers to the medium of transmission that used by the speaker and the expectation of the speaker regarding what the language will do for them. The three elements help clarify the interrelationship of language to determine the intended meaning.

\section{References}

Austin, J.L. 1970. How to Do Things with Words. New York: Oxford University Press.

Halliday, M.A.K \&Hasan, R. 1985.Language, context, and text: Aspects of language in a socialsemiotic perspective. Deakin University Press

Levinson, C. Stephen. 1987. Pragmatics. Cambridge University Press.

Searle, J.R. 1976. A Classification of Illocutionary Acts. Language in 
Society. Vol. 5, No.1, April, pp. 123.

Searle \& Vanderveken. 1985. Foundations of Illocutionary Logic. Cambridge: Cambridge University Press.

The Inaugural Address [Internet]. The White House, Washington. Available from: https://www.whitehouse.gov/inaug ural-address [Accessed 15 May 2017].

Vanderveken, Daniel. 1990. Meaning and Speech Acts: Volume 1, Principles of Language Use. Cambridge: Cambridge University Press. 